DOI: https://doi.org/10.47405/mjssh.v5i7.656

\begin{tabular}{|c|c|}
\hline 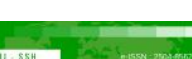 & Malaysian Journal of Social Sciences and Humanities (MJSSH) \\
\hline Malaysian Journal of & Volume 5, Issue 7, July 2020 \\
\hline (MJ. SSH) & e-ISSN : 2504-8562 \\
\hline & $\begin{array}{l}\text { Journal home page: } \\
\text { www.msocialsciences.com }\end{array}$ \\
\hline
\end{tabular}

\title{
Aplikasi Google Classroom dalam Pembelajaran Sejarah: Dari Perspektif Murid
}

\author{
M. Kaviza ${ }^{1}$ \\ ${ }_{1}^{1}$ Pusat Pengajian Pendidikan dan Bahasa Moden, Universiti Utara Malaysia (UUM) \\ Correspondence: M. Kaviza (kavizakaviza@yahoo.com)
}

\begin{abstract}
Abstrak
Kajian tinjauan ini bertujuan untuk mengenal pasti tahap perspektif terhadap pembelajaran sejarah dengan aplikasi Google Classroom dari aspek pengetahuan, kemahiran dan sikap dalam kalangan murid. Seramai 114 orang murid tingkatan empat yang ditentukan berdasarkan teknik persampelan rawak mudah merupakan sampel kajian ini. Instrumen kajian ini merupakan soal selidik. Data kajian ini dianalisis secara statistik deskriptif iaitu min dan sisihan piawai melalui perisian IBM SPSS. Dapatan kajian ini menunjukkan bahawa tahap perspektif terhadap pengetahuan, kemahiran dan sikap dalam pembelajaran sejarah dengan aplikasi Google Classroom berada pada tahap sederhana dalam kalangan murid. Implikasi kajian ini telah memaparkan maklumat kepada guru-guru sejarah untuk mengintegrasikan aplikasi Google Classroom dengan berkesan dalam proses pengajaran dan pembelajaran dalam kalangan murid.
\end{abstract}

Kata kunci: Google Classroom, pengetahuan, kemahiran, sikap, pembelajaran sejarah, murid

\section{The Application of Google Classroom in Learning of History: From Students' Perspectives}

\begin{abstract}
The survey study aims to identify the perspectives towards learning of history with Google Classroom application in terms of knowledge, skill and attitude among students. A total of 114 form four students which are selected through simple random sampling technique involved in this study. The instrument of this study is a questionnaire. The data of this study were analyzed descriptively, such as means and standard deviation using IBM SPSS software. The findings of this study indicated that the perspectives of the knowledge, skill dan attitude level towards learning of history with Google Classroom is at moderate level among students. The implications of this study provided information to history teachers to integrate Google Classroom effectively in teaching and learning process among students.
\end{abstract}

Keywords: Google Classroom, knowledge, skill, attitude, learning of history, students 


\section{Pengenalan}

Perkembangan pembelajaran atas talian yang semakin pesat dalam arus globalisasi ini telah membolehkan pengaplikasian dan pengintegrasian pelbagai jenis teknologi dan media dalam proses pengajaran dan pembelajaran. Aplikasi Google Classroom merupakan antara platform yang boleh digunakan sebagai platform pembelajaran bagi melaksanakan pembelajaran atas talian (Swita \& Heri, 2019). Aplikasi Google Classroom merupakan platform pembelajaran yang percuma yang berteraskan internet yang mempunyai pelbagai fungsi dan pautan aplikasi yang dapat membolehkan guru-guru merancang dan melaksanakan proses pengajaran dan pembelajaran dengan baik. Hal ini disebabkan oleh aplikasi Google Classroom dilengkapi dengan kemudahan mengedar dan berkomunikasi terhadap tugasan yang diberikan dengan lebih mudah, disamping dapat menghantar pesanan atau arahan dengan memulakan sesi perbincangan serta merta melalui perkongsian bahan dan penjanaan interaksi dua hala (Hemrungrote, Jakkaew \& Assawaboonme, 2017). Adalah tidak dinafikan bahawa aplikasi Google Classroom memainkan peranan penting dalam melaksanakan proses pembelajaran dan pemudahcaraan yang bermakna (Leijla, Edmond, Hirije, Arbana \& Marika, 2017; Hilyah \& Mochammad, 2019; Eman, 2020), namun penggunaannya dalam proses pembelajaran sejarah adalah didapati berpotensi untuk dipraktikkan rentetan daripada dapatan kajian Fitriningtiyas, Umamah dan Sumardi (2018) yang membincangkan keperluan untuk membangunkan proses pembelajaran sejarah melalui aplikasi Google Classroom berdasarkan Model ADDIE. Sungguhpun begitu, terdapat satu keperluan kepada pengkaji kajian ini untuk meninjau perspektif murid terhadap pembelajaran sejarah dengan aplikasi Google Classroom dari aspek pengetahuan, kemahiran dan sikap terlebih dahulu. Tinjauan ini adalah perlu bagi mendapatkan gambaran awal tentang perspektif murid terhadap penggunaan aplikasi Google Classroom dalam proses pembelajaran sejarah mereka bagi memudahkan guru-guru untuk mereka bentuk aktiviti pembelajaran atas talian yang berkesan melalui aplikasi Google Classroom. Justeru, kajian ini adalah bertujuan untuk mengenal pasti tahap perspektif terhadap pembelajaran sejarah dengan aplikasi Google Classroom dari aspek pengetahuan, kemahiran dan sikap dalam kalangan murid.

\section{Objektif Kajian}

Objektif kajian ini ialah untuk mengenal pasti tahap perspektif terhadap pembelajaran sejarah dengan aplikasi Google Classroom dalam kalangan murid dari aspek pengetahuan, kemahiran dan sikap.

\section{Persoalan Kajian}

Persoalan kajian ini ialah:

i. Apakah tahap perspektif terhadap pembelajaran sejarah dengan aplikasi Google Classroom dalam kalangan murid?

ii. Apakah tahap perspektif dari aspek pengetahuan terhadap pembelajaran sejarah dengan aplikasi Google Classroom dalam kalangan murid?

iii. Apakah tahap perspektif dari aspek kemahiran terhadap pembelajaran sejarah dengan aplikasi Google Classroom dalam kalangan murid?

iv. Apakah tahap perspektif dari aspek sikap terhadap pembelajaran sejarah dengan aplikasi Google Classroom dalam kalangan murid?

\section{Metod Kajian}

Kajian berbentuk tinjauan dengan menggunakan soal selidik ini melibatkan seramai 114 orang murid Tingkatan Empat sebagai sampel kajian ini yang telah dipilih melalui teknik persampelan rawak mudah. Soal selidik yang diadaptasi yang telah disahkan kesahan kandungan serta konstruknya oleh pakar penilai dalam bidang pendidikan sejarah merupakan instrumen kajian ini. Nilai Cronbach Alpha 
iaitu 0.95 bagi soal selidik telah menunjukkan bahawa instrumen tersebut mempunyai nilai kebolehpercayaan yang baik dan boleh diterima dalam kajian ini (Nunnally, 1978). Data kajian ini dianalisis secara statistik deskriptif iaitu min dan sisihan piawai melalui perisian IBM SPSS. Interpretasi tahap kesediaan dalam kajian ini ditentukan melalui interpretasi tahap yang diberikan oleh Jamil Ahmad (2002) seperti ditunjukkan pada Jadual 1.

Jadual 1: Interpretasi Min dan Tahap

\begin{tabular}{ll}
\hline Skor Min & Tahap \\
\hline $3.67-5.00$ & Tinggi \\
$2.34-3.66$ & Sederhana \\
$1.00-2.33$ & Rendah \\
\hline
\end{tabular}

Sumber: Adaptasi daripada Jamil Ahmad (2002)

\section{Dapatan dan Perbincangan Kajian}

\section{Tahap Perspektif Terhadap Pembelajaran Sejarah dengan Aplikasi Google Classroom}

Berdasarkan Jadual 2, tahap perspektif terhadap pembelajaran sejarah dengan aplikasi Google Classroom $(M=3.34, S D=0.63)$ berada pada tahap sederhana. Tahap perspektif yang sederhana yang dilaporkan dalam kajian ini adalah sealiran dengan dapatan kajian Nor Zanira dan Hafizul (2019) yang telah menjelaskan bahawa tahap penerimaan murid Tingkatan Empat terhadap penggunaan aplikasi Google Classroom dalam Pendidikan Islam berdasarkan Model UTAUT adalah baik dan dapatan kajian Jeya dan Brandford (2019) yang telah melaporkan bahawa murid-murid dalam pendidikan tinggi mempunyai persepsi positif terhadap penerimaan aplikasi Google Classroom berdasarkan Model UTAUT sebagai platform pembelajaran mudah alih (mobile platform). Kedua-dua dapatan kajian tersebut telah menjelaskan bahawa aplikasi Google Classroom adalah berperanan sebagai alat pengajaran dan pembelajaran yang dapat membentuk proses pembelajaran yang bermakna dan efektif yang telah menyokong dapatan kajian ini. Tambahan pula, dapatan kajian Fitriningtiyas et al (2018) yang menjelaskan kebaikan penggunaan aplikasi Google Classroom sebagai media pembelajaran sejarah turut telah menyokong dapatan kajian ini secara tidak langsung. Sungguhpun begitu, tahap perspektif yang sederhana yang dilaporkan dalam kajian ini adalah disebabkan oleh murid-murid masih berada pada tahap penggunaan peringkat awal sejak ianya disarankan dalam proses pembelajaran. Justeru, dapat dirumuskan bahawa tahap perspektif terhadap pembelajaran sejarah dengan aplikasi Google Classroom adalah berada pada tahap sederhana dalam kalangan murid dalam kajian ini.

Jadual 2: Tahap Perspektif Terhadap Pembelajaran Sejarah dengan Aplikasi Google Classroom

\begin{tabular}{lllll}
\hline Konstruk & $\boldsymbol{N}$ & Min $(\boldsymbol{M})$ & $\begin{array}{l}\text { Sisihan Piawai } \\
(\mathbf{S D})\end{array}$ & Tahap \\
\hline $\begin{array}{l}\text { Perspektif terhadap Aplikasi } \\
\text { Google Classroom }\end{array}$ & 114 & 3.34 & 0.63 & Sederhana \\
\hline
\end{tabular}

\section{Tahap Perspektif dari aspek Pengetahuan Terhadap Pembelajaran Sejarah dengan Aplikasi Google Classroom}

Berdasarkan Jadual 3, tahap perspektif dari aspek pengetahuan terhadap pembelajaran sejarah dengan aplikasi Google Classroom $(M=3.47, S D=0.87)$ adalah berada pada tahap sederhana. Tahap perspektif dari aspek pengetahuan terhadap pembelajaran sejarah dengan aplikasi Google Classroom yang dilaporkan berada pada tahap sederhana dalam kajian ini adalah konsisten dengan dapatan kajian Zhou, Simpson dan Domizi (2012) yang telah melaporkan bahawa kebanyakan murid melaporkan bahawa mereka adalah tidak begitu mengetahui penggunaan aplikasi Google Docs disebabkan oleh aplikasi tersebut adalah masih baharu, namun sebanyak 93 peratus murid-murid telah berpendapat 
bahawa aplikasi tersebut merupakan aplikasi atas talian yang berguna dalam aktiviti pembelajaran berkumpulan. Pendapat yang sama juga telah diutarakan oleh Zaizdee (2018) dalam kajiannya yang telah melaporkan bahawa murid-murid bertanggapan baik terhadap penggunaan Google Docs dan Google Classroom sebagai alat pembelajaran kolaboratif atas talian dalam pembelajaran tatabahasa dan mereka telah bersedia untuk menggunakan aplikasi tersebut dalam kursus-kursus akan datang telah dapat menyokong dapatan kajian ini. Hal ini demikian kerana murid-murid mengetahui dan menyedari kebaikan penggunaan aplikasi Google Classroom dalam membentuk proses pembelajaran yang baik. Justeru, dapat dirumuskan bahawa tahap perspektif dari aspek pengetahuan terhadap pembelajaran sejarah dengan aplikasi Google Classroom adalah berada pada tahap sederhana dalam kalangan murid dalam kajian ini.

Jadual 3: Tahap Perspektif dari aspek Pengetahuan Terhadap Pembelajaran Sejarah dengan Aplikasi Google Classroom

\begin{tabular}{lllll}
\hline Konstruk & $\boldsymbol{N}$ & Min $(\boldsymbol{M})$ & $\begin{array}{l}\text { Sisihan Piawai } \\
(\boldsymbol{S D})\end{array}$ & Tahap \\
\hline Pengetahuan & 114 & 3.47 & 0.87 & Sederhana \\
\hline
\end{tabular}

\section{Tahap Perspektif dari aspek Kemahiran Terhadap Pembelajaran Sejarah dengan Aplikasi Google Classroom}

Berdasarkan Jadual 4, tahap perspektif dari aspek kemahiran terhadap pembelajaran sejarah dengan aplikasi Google Classroom $(M=3.45, S D=0.90)$ adalah berada pada tahap sederhana. Tahap perspektif dari aspek kemahiran terhadap pembelajaran sejarah dengan aplikasi Google Classroom yang berada pada tahap sederhana dalam kajian ini adalah konsisten dengan dapatan kajian Ratnaningsuh (2019) secara kualitatif yang telah melaporkan bahawa murid-murid berpendapat bahawa mereka lebih berkemahiran dari segi penulisan dan komunikasi dalam menyiapkan tugasan melalui aplikasi Google Classroom. Dapatan Ratnaningsuh (2019) ini adalah bertepatan dengan dapatan kajian Ghatage (2019) yang telah melaporkan bahawa tahap penerimaan guru dan murid terhadap aplikasi Google Classroom sebagai alat yang mudah digunakan adalah baik, terutamanya dalam melaksanakan aktiviti pembelajaran yang bersifat kreatif dan inovatif yang dapat menjana kemahiran dan pencapaian yang berkesan. Kedua-dua dapatan kajian tersebut dapat menyokong dapatan kajian ini secara tidak langsung walaupun tahap perspektif dari aspek kemahiran terhadap pembelajaran sejarah dengan aplikasi Google Classroom berada pada tahap sederhana. Hal ini demikian kerana penggunaan aplikasi Google Classroom secara berkesan, terancang dan sistematik dalam proses pembelajaran dan pemudahcaraan dapat mempengaruhi penguasaan kemahiran dalam kalangan murid secara berterusan. Justeru, dapat dirumuskan bahawa tahap perspektif dari aspek kemahiran terhadap pembelajaran sejarah dengan aplikasi Google Classroom adalah berada pada tahap sederhana dalam kalangan murid dalam kajian ini.

Jadual 4: Tahap Perspektif dari aspek Kemahiran Terhadap Pembelajaran Sejarah dengan Aplikasi Google Classroom

\begin{tabular}{lllll}
\hline Konstruk & $\boldsymbol{N}$ & Min $(\boldsymbol{M})$ & $\begin{array}{l}\text { Sisihan Piawai } \\
(\boldsymbol{S D})\end{array}$ & Tahap \\
\hline Kemahiran & 114 & 3.45 & 0.90 & Sederhana \\
\hline
\end{tabular}

\section{Tahap Perspektif dari aspek Sikap Terhadap Pembelajaran Sejarah dengan Aplikasi Google Classroom}

Berdasarkan Jadual 5, tahap perspektif dari aspek sikap terhadap pembelajaran sejarah dengan aplikasi Google Classroom $(M=3.44, S D=0.93)$ adalah berada pada tahap sederhana. Tahap perspektif dari aspek sikap terhadap pembelajaran sejarah dengan aplikasi Google Classroom yang dilaporkan berada pada tahap sederhana dalam kajian ini adalah sealiran dengan dapatan kajian Izwan, Jastini dan Sarah Syamimi (2016) yang telah melaporkan bahawa kebanyakan murid berpuas hati dengan penggunaan aplikasi Google Classroom sebagai alat pengajaran dan pembelajaran serta dapatan kajian Sibuea 
(2019) yang telah melaporkan bahawa murid-murid bersikap puas hati terhadap proses pembelajaran mereka melalui aplikasi Google Classroom. Tahap perspektif dari aspek sikap yang berada pada tahap sederhana dalam pembelajaran sejarah dalam kajian ini adalah disebabkan oleh murid-murid telah mula melibatkan diri dengan penggunaan aplikasi Google Classroom dalam aktiviti pembelajaran mereka dan dan pendapat ini adalah selari dengan tinjauan awal yang dijalankan oleh pengkaji yang telah mendapati bahawa tahap kesediaan murid terhadap penggunaan aplikasi Google Classroom sebagai platform pembelajaran sejarah berada pada tahap sederhana (Kaviza, 2020). Justeru, dapat dirumuskan bahawa tahap perspektif dari aspek sikap terhadap pembelajaran sejarah dengan aplikasi Google Classroom adalah berada pada tahap sederhana dalam kalangan murid dalam kajian ini.

Jadual 5: Tahap Perspektif dari aspek Sikap Terhadap Pembelajaran Sejarah dengan Aplikasi Google Classroom

\begin{tabular}{lllll}
\hline Konstruk & $\boldsymbol{N}$ & Min $(\boldsymbol{M})$ & $\begin{array}{l}\text { Sisihan Piawai } \\
(\boldsymbol{S D})\end{array}$ & Tahap \\
\hline Sikap & 114 & 3.44 & 0.93 & Sederhana \\
\hline
\end{tabular}

\section{Kesimpulan}

Kesimpulannya, dapatan kajian ini telah menunjukkan bahawa tahap perspektif terhadap pembelajaran sejarah dengan aplikasi Google Classroom dari aspek pengetahuan, kemahiran dan sikap berada pada tahap sederhana dalam kalangan murid. Justeru, semua pihak perlu bekerjasama dalam meningkatkan tahap perspektif terhadap penggunaan aplikasi Google Classroom dalam proses pembelajaran sejarah selaras dengan usaha untuk membentuk proses pembelajaran yang menarik bagi meningkatkan minat dan motivasi murid secara berterusan.

\section{Rujukan}

Eman, A-R.A. (2020). A review of research into Google Classroom Apps in the process of English Language Learning and Teaching. Arab World English Journal, 11(1), 399-418.

Fitriningtiyas, D.A., Umamah, N \& Sumardi (2018). Google Classroom: as a media of learning history. ICEGE 2018, 1-8.

Ghantage, M.M (2019). Use of Google Classroom in teaching. International Journal of English Language and Literature in Humanities, 7(3), 3018-335.

Hemrungrote, S., Jakkaew, P \& Assawaboonmee, S. (2017). Deployment of Google Classroom to enhance SDL cognitive skills: A case study of introduction to information technology course. 2017 International Conference on Digital Arts, Media and Technology (ICDAMT), Chiang Mai, 200-204.

Hilyah, A \& Mochammad, S.S. (2019). Penggunaan Google Classroom pada mata kuliah Pai. Journal of Education and Management Studies, 2(4), 29-34.

Izwan Nizal Mohd Shaharanee, Jastini Mohd Jamil \& Sarah Syamimi Mohammad Rodzi. (2016). The application of Google Classroom as atool for teaching and learning. Journal of Telecomunication Electronic and computer Engineering, 8(10), 5-8.

Jeya, A.K \& Brandford, W. (2019). Google Classroom for mobile learning in higher education: modeling the initial perceptions of students. Education and Information Technologies, 1-25.

Kaviza, M. (2020). Kesediaan Murid Terhadap Penggunaan Aplikasi Google Classroom Sebagai Platform Pembelajaran Sejarah. Malaysian Journal of Social Sciences and Humanities (MJSSH), 5(4), $108-115$.

Leijla, A.B., Edmond, J., Hirije, A.A., Arbana, K \& Marika, A.T. (2017). A Google Classroom-based learning management system: Empirical evidence from SEEU. Entrenova Proceedings, 8-16

Nor Zanira Abdul Manan \& Hafizul Fahri Hanafi (2019). Google Classroom: Student's acceptance using UTAUT Model. JAPPA Journal: Journal of Applied Art, 1(1), 64-72. 
Rtananingsih, P.W. (2019). The use of Google Classroom application for writing and speaking in english education class. Indonesian EFL Journal: Journal of ELT, Lingustics and Literature, 5(1), 93-110.

Sibuea, T.F. B. (2019). Students perceptions on the use of Google Classroom to support blended learning for the pengantar linguistic umum course. LINGUA: Jurnal Ilmiah Bahasa dan Budaya, 14, 1-14.

Swita, A.H \& Heri, P. (2019). Pemanfaatan Google Classroom sebagai media pembelajaran online di universitas dian Nuswantaoro. WACANA, 18(2), 225-233.

Zaiadee, M.K (2018). EFL student's perceptions toward using Google Docs and Google Classroom as online collaborative tools in learning granmmar. Applied Lingusitics Research Journal, 2(2), 3348.

Zhou, W, Simpson, E \& Damizi, D.P. (2012). Google Docs in an out of class collaborative writing activity. International Journal of Teaching and Learning in Higher Education, 24(3), 359-375. 